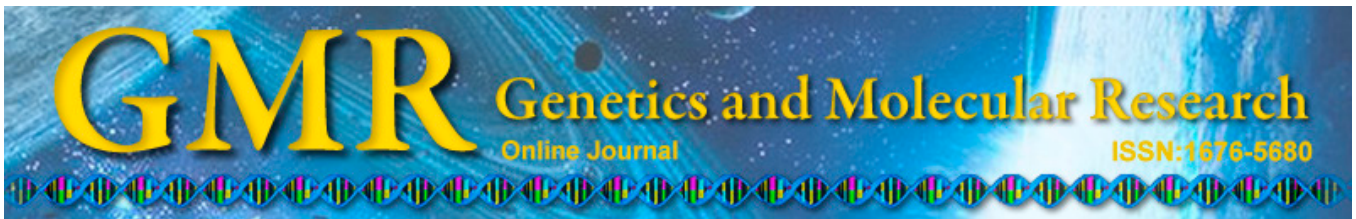

\title{
DNA barcoding for efficient identification of Ixiolirion species (Ixioliriaceae)
}

\author{
Y. Zhao ${ }^{1,2}$, Y. Li ${ }^{3}$, Y. Liu' ${ }^{2}$ and Y.F. Yang ${ }^{1}$ \\ ${ }^{1}$ Key Laboratory of Vegetation Ecology, Ministry of Education, \\ Institute of Grassland Science, Northeast Normal University, \\ Changchun, China \\ ${ }^{2}$ School of Chemistry \& Bioscience, Yili Normal University, Yining, China \\ ${ }^{3}$ Xinjiang Institute of Ecology and Geography, \\ Chinese Academy of Sciences, Urumqi, China \\ Corresponding author: Y.F. Yang \\ E-mail: yangyf@nenu.edu.cn
}

Genet. Mol. Res. 14 (1): 1903-1910 (2015)

Received February 27, 2014

Accepted September 24, 2014

Published March 13, 2015

DOI http://dx.doi.org/10.4238/2015.March.13.19

\begin{abstract}
Ixiolirion is a genus of unresolved taxonomy. DNA barcoding is a technique that allows species identification using standardized DNA sequences. In this study, a total of 23 individuals, representing 2 Chinese Ixiolirion species, were sampled to test the effectiveness of 3 DNA barcodes [internal transcribed spacer (ITS), chloroplast tRNA intron, and megakaryocyte-associated tyrosine kinase] for species identification. Of the 3 DNA barcodes, ITS displayed the maximum level of polymerase chain reaction and sequencing success as well as the highest sequence variation. Intra-specific sequence distances of ITS, chloroplast tRNA intron, and megakaryocyte-associated tyrosine kinase were 0,0 , and $0-0.1 \%$, respectively, with $8.3,0.6$, and $0.5 \%$ as mean inter-specific distances, respectively. All individuals of each species formed a monophyletic group (clade) in the neighborjoining trees constructed using the 3 single-DNA barcodes. Our results demonstrated that ITS, chloroplast tRNA intron, and megakaryocyteassociated tyrosine kinase DNA markers could be used to efficiently
\end{abstract}


identify Ixiolirion species. Our results indicate that DNA barcoding provides a reliable and effective means for discriminating Ixiolirion species, and is a robust tool for resolving taxonomic controversies of Ixiolirion in combination with morphology-based taxonomy.

Key words: DNA barcoding; Ixiolirion; Species identification; Taxonomy

\section{INTRODUCTION}

Ixiolirion Fisch. ex Herb is the single genus that constitutes the family Ixioliriaceae in the order Asparagales (Chase et al., 2000; Bremer et al., 2009; Kim et al., 2010) and is mainly distributed in Central and Southwest Asia. Ixiolirion are perennial herbs characterized by globose bulbs, linear leaves, paniculate or umbellate inflorescence, and oblong-clavate, capsule fruits. The taxonomy of Ixiolirion is controversial. Regel (1878) first described Ixiolirion species with the perianth tube as a new genus named Kolpakowskianum Regel. However, Regel (1879) next suggested that this new genus should be recognized as synonymous with Ixiolirion Herb. Moreover, a large number of synonyms were used for Ixiolirion and the species number in the genus has not been determined yet. For instance, Townsend and Guest (1985) considered I. pallasii to be a synonym of I. tataricum (Pallas) Herbert. Qian (1984) considered I. kolpakowskianum synonymous with I. tataricum var. ixiolirioides; Govaerts (2011) considered I. ledebourii, I. montanum, I. sintenisii Leichtlin, I. macranthum, I. tataricum var. intermedium, and I. tataricum var. ledebourii to be synonyms of I. tataricum var. tataricum. According to Govaerts (2011), Ixiolirion included 4 species.

There are 2 Ixiolirion species in China: I. songaricum P. Yan and I. tataricum (Pallas) Herbert, although only 1 Ixiolirion species was acknowledged until recently. Based on specimen examination and field observation, Yan (1995) suggested a new species, I. songaricum, present in the desert and grassland zones in Xinjiang. Interestingly, the 2 species show similar distribution, habitats, and morphological characteristics and only slightly differ from each other. I. tataricum has spreading perianth segments, purple filaments, and basifixed anthers, whereas $I$. songaricum has recurved perianth segments, white filaments, and dorsifixed anthers. Recently, $I$. tataricum (Pallas) Herbert subsp montanum (Labill.) was identified in an ethnopharmacological survey of medicinal plants in Maden (Elazig-Turkey), among the curative herbs of Maden used in different parts of the world for treating various diseases (Cakilcioglu et al., 2011). Notably, $I$. tataricum subsp montanum is rare in Maden and is classified as a vulnerable species (Khatun et al., 2012). Although I. songaricum and I. tataricum show some differences, similar mature fruit types and perianth color upon drying make specimen identification difficult.

DNA barcoding has provided a new approach for accurate and rapid species-level identification among plants based on short-DNA regions (Hebert et al., 2004). The Consortium for the Barcode of Life (CBOL) Plant Working Group (2009) recommended rbcL + matK as core barcodes for plant identification. The 2-locus barcode $(r b c L+m a t K)$ was recently endorsed for ferns (Li et al., 2011). The nuclear ribosomal internal transcribed spacer (ITS) and plastid psbA-trnH region were suggested as complementary plant barcoding regions because of their rapid evolution rates (CBOL Plant Working Group, 2009). Other chloroplast regions, such as the trnL intron and trnL-trnF interspacer, have been used as DNA barcodes in many studies because of their high-sequence variation. 
In the present study, matK, ITS, and trnL intron were evaluated for their discriminatory power for identifying I. songaricum and I. tataricum, as well as to assess the congruence of traditional taxonomic treatments based on morphological data, with DNA barcoding results.

We found that matK, ITS, and trnL intron DNA barcodes efficiently identified Ixiolirion species, suggesting that DNA barcoding is an efficient method for discriminating Ixiolirion species. Therefore, DNA barcoding is a robust tool that can be used to resolve taxonomic controversies of Ixiolirion and other plant groups, in combination with morphology-based taxonomy.

\section{MATERIAL AND METHODS}

\section{Specimen sampling}

A total of 23 individual plants were collected from various areas of Xinjiang, with 13 I. songaricum sampled from 3 regions and 10 I. tataricum sampled from 4 sites. All new sequences obtained were deposited in GenBank. Voucher specimen numbers, geographic location information, and GenBank accession numbers are listed in Table 1.

\begin{tabular}{|c|c|c|c|c|c|}
\hline \multirow[t]{2}{*}{ Taxon } & \multirow[t]{2}{*}{ Location } & \multirow[t]{2}{*}{ Voucher } & \multicolumn{3}{|c|}{ GenBank accession No. } \\
\hline & & & ITS & trnL intron & matK \\
\hline I. songaricum & China, Shihezi & ZY-SHZ-04 & KF261055 & KF261078 & KF261098 \\
\hline I. songaricum & China, Shihezi & ZY-SHZ-01 & KF261056 & KF261079 & KF261099 \\
\hline I. songaricum & China, Shihezi & ZY-SHZ-02 & KF261057 & KF261080 & KF261100 \\
\hline I. songaricum & China, Shihezi & ZY-SHZ-03 & KF261058 & KF261081 & KF261101 \\
\hline I. songaricum & China, Urumqi & ZY-ZZS-04 & KF261059 & - & - \\
\hline I. songaricum & China, Urumqi & ZY-ZZS-03 & KF261060 & - & KF261102 \\
\hline I. songaricum & China, Urumqi & ZY-ZZS-01 & KF261061 & KF261082 & KF261103 \\
\hline I. songaricum & China, Gongliu & ZY-353 & KF261062 & KF261083 & KF261104 \\
\hline I. songaricum & China, Urumqi & ZY-ZZS-06 & KF261063 & KF261084 & KF261105 \\
\hline I. songaricum & China, Urumqi & ZY-ZZS-07 & KF261064 & KF261085 & KF261106 \\
\hline I. songaricum & China, Urumqi & ZY-ZZS-08 & KF261065 & KF261086 & KF261107 \\
\hline I. songaricum & China, Urumqi & ZY-ZZS-09 & KF261066 & KF261087 & KF261108 \\
\hline I. songaricum & China, Urumqi & ZY-ZZS-10 & KF261067 & KF261088 & - \\
\hline I. tataricum & China, Shihezi & Y-SHZ-03 & KF261068 & KF261089 & KF261109 \\
\hline I. tataricum & China, Shihezi & Y-SHZ-01 & KF261069 & KF261090 & KF261110 \\
\hline I. tataricum & China, Gongliu & Y-371-3 & KF261070 & KF261091 & KF261111 \\
\hline I. tataricum & China, Gongliu & Y-371-2 & KF261071 & KF261092 & KF261112 \\
\hline I. tataricum & China, Yumin & Y-293-1 & KF261072 & KF261093 & KF261113 \\
\hline I. tataricum & China, Yumin & Y-293-3 & KF261073 & KF2610794 & KF261114 \\
\hline I. tataricum & China, Urumqi & Y-ZZS-03 & KF261074 & - & KF261115 \\
\hline I. tataricum & China, Urumqi & Y-ZZS-04 & KF261075 & KF2610795 & - \\
\hline I. tataricum & China, Urumqi & Y-ZZS-01 & KF261076 & KF2610796 & KF261116 \\
\hline I. tataricum & China, Urumqi & Y-ZZS-06 & KF261077 & KF2610797 & - \\
\hline Galanthusplicatus & & & AY101304.1 & AF104799.1 & AY101337.1 \\
\hline
\end{tabular}

$(-)=$ no sequence obtained.

\section{DNA extraction, polymerase chain reaction (PCR) amplification, and sequencing}

Genomic DNA was extracted either from fresh or silica gel-dried leaves using the hexadecyltrimethylammonium bromide (CTAB) method (Doyle and Doyle, 1987). The universal primers ITS5 and ITS4 (White et al., 1990) were used to amplify the ITS region. Previously designed universal primers (Taberlet et al., 1991) were used to amplify the trnL intron. A new 
primer pair was used to amplify matK: forward primer, 5'-CGCTTTTCTTTCAGGAGTCT-3'; reverse primer, 5'-TCAAAGGATTTGTTTTGGGG-3'. The 50- $\mu \mathrm{L}$ PCR mixtures were composed of $2 \mu \mathrm{L}$ DNA template, $5 \mu \mathrm{L} 10 \mathrm{X}$ buffer containing $25 \mathrm{mM} \mathrm{MgCl}, 0.2 \mathrm{mM}$ dNTPs, $0.5 \mu \mathrm{M}$ of each primer, $2 \mathrm{U}$ rTaq polymerase (Takara, Shiga, Japan), and nuclease-free water. PCRs were carried out as follows: 5 min initial denaturation at $94^{\circ} \mathrm{C} ; 35$ cycles of $30 \mathrm{~s}$ denaturation at $95^{\circ} \mathrm{C}, 1 \mathrm{~min}$ annealing at $52^{\circ} \mathrm{C}$, and elongation at $72^{\circ} \mathrm{C}(1 \mathrm{~min}$ for ITS and trnL intron and $1.5 \mathrm{~min}$ for matK); a final elongation for $10 \mathrm{~min}$ at $72^{\circ} \mathrm{C}$. PCR products were analyzed on $1.2 \%$ TAE agarose gels and purified using the Tiangen purification kit (Tiangen Biotech, Beijing, China) according to manufacturer instructions. The purified PCR products were sequenced by BGI (Beijing, China). ITS and trnL intron were unidirectionally sequenced, while matK was bidirectionally sequenced.

\section{Sequence analysis}

Sequences were assembled and edited using DNAMAN version 7.0 (Lynnon Corporation, Quebec, Canada). Sequences were aligned using the ClustalW tool in the MEGA 5 package, as previously described (Tamura et al., 2011). Inter- and intra-specific genetic distances were calculated using the Kimura-2-parameter (K2P) model in MEGA 5.0. To evaluate the effectiveness of barcoding candidate sequences for species discrimination, we conducted a tree-based analysis. A phylogenetic tree was predicted using neighbor-joining (NJ) tool in MEGA 5.0 with K2P model data and gamma distributed rates among sites. Pairwise deletion was used for gaps and missing data treatment. Bootstrap values were calculated with 1000 replicates. Galanthus plicatus was chosen as the out-group control.

\section{RESULTS}

\section{PCR amplification and sequencing}

The efficiency of PCR amplification and sequencing is an important index for evaluating a candidate DNA barcode. We generated 61 new sequences, including 23, 20, and 19 sequences for ITS, trnL intron, and matK, respectively (Table 2). The most successful PCR rate was observed for ITS (100\%), followed by trnL (95.7\%) and matK (91.3\%). Sequencing success ranged from $82.6 \%$ for matK to $100 \%$ for ITS (Table 2 ).

Table 2. Statistics of three DNA barcodes used in this study.
\begin{tabular}{lcccccc}
\hline & Aligned length $(\mathrm{bp})$ & Constant site & Variable site & PCR success & Sequencing success & Individuals examined \\
\hline ITS & 722 & 668 & 53 & $100.0 \%(23 / 23)$ & $100.0 \%(23 / 23)$ & 23 \\
trnL & 542 & 539 & 3 & $95.7 \%(22 / 23)$ & $86.9 \%(20 / 23)$ & 23 \\
matK & 1311 & 1304 & 7 & $91.3 \%(21 / 23)$ & $82.6 \%(19 / 23)$ & 23 \\
\hline
\end{tabular}

\section{Sequences analyses}

After deletion of ambiguous terminal sequences, the aligned data resulted in sequence fragments of 722, 542 and $1311 \mathrm{bp}$ for ITS, trnL intron and matK, respectively (Table 2). The intra-specific distance of ITS was $0-0.1 \%$ in the two species (Table 2). The trnL intron and matK 
gene sequences of each species were identical with an intra-specific distance of 0 (Table 2). The low intra-specific divergence indicated a low genetic diversity between populations from different geographic locations. The highest mean inter-specific K2P distance was found in nuclear ITS with a value of $8.3 \%$ (Table 3 ). The inter-specific distances for trnL intron and matK were nearly the same between the two species, with values of 0.6 and $0.5 \%$, respectively (Table 3 ). Interestingly, an 11-bp indel was observed in trnL intron between the two species (Table 4).

Table 3. Intra- and inter-specific distances of Ixiolirion species estimated using the K2P model.

\begin{tabular}{lccc}
\hline & I. tataricum & I. songaricum & Inter-specific distance \\
\hline ITS & 0.001 & 0 & 0.083 \\
trnL intron & 0 & 0 & 0.006 \\
matK & 0 & 0 & 0.005 \\
\hline
\end{tabular}

Table 4. TrnL intron sequence variation among the 2 Ixiolirion species.
\begin{tabular}{lccccc} 
\\
\hline 271 & 313 & 317 & $321-331$ \\
\hline I. songaricum & $\mathrm{G}$ & $\mathrm{T}$ & $\mathrm{A}$ & TATATATTATA \\
I. tataricum & $\mathrm{A}$ & $\mathrm{A}$ & $\mathrm{C}$ & - \\
\hline
\end{tabular}

\section{Phylogenetic analyses}

A tree-based NJ method was used for Ixiolirion species identification. NJ analysis of ITS, trnL intron, and matK gene sequences revealed that all individuals of each species formed a monophyletic group (Figures 1-3), indicating that each DNA barcode fully discriminated between I. songaricum and I. tataricum.

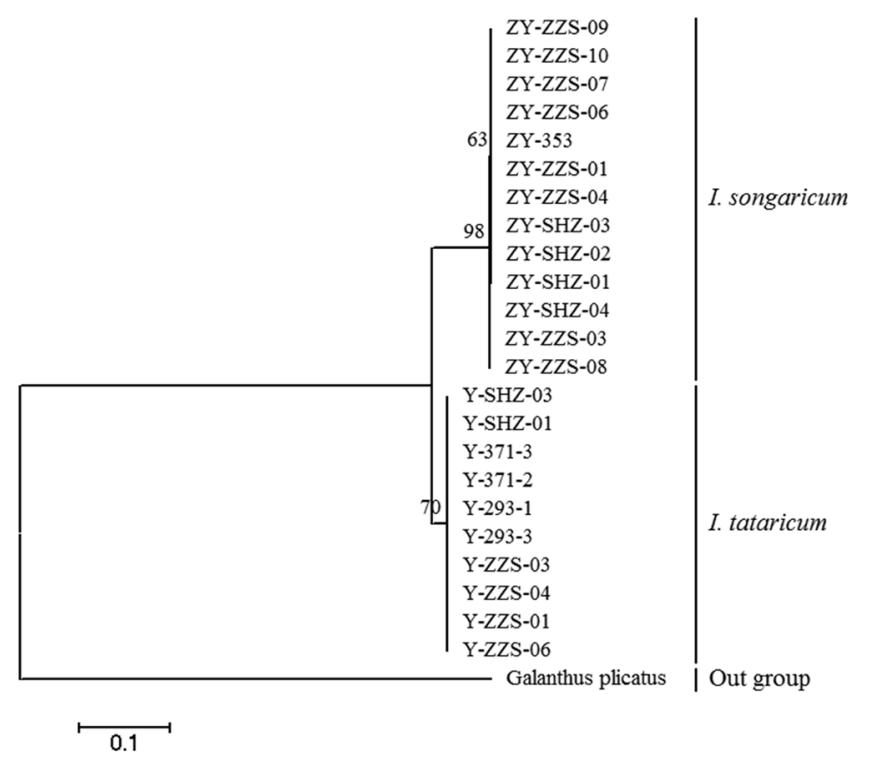

Figure 1. Neighbor-joining tree of Ixiolirion species inferred from ITS sequences. Bootstrap values greater than $50 \%$ are shown above branches. Species are shown to the right. 


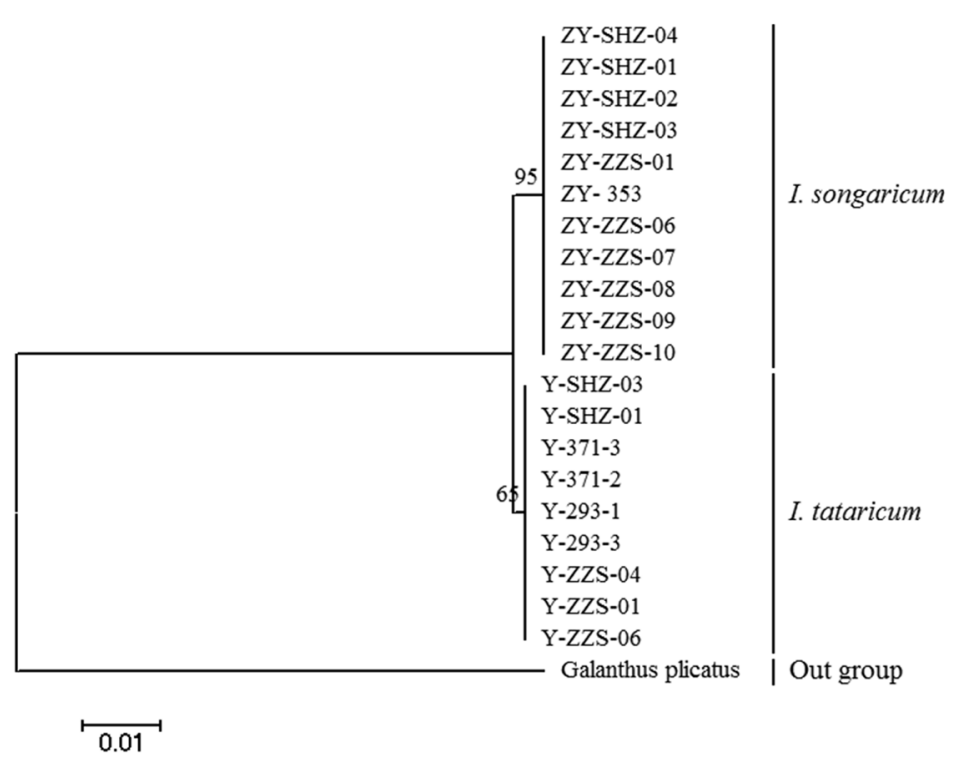

Figure 2. Neighbor-joining tree of Ixiolirion species inferred from trnL intron sequences. Bootstrap values greater than $50 \%$ are shown above branches. Species are shown to the right.

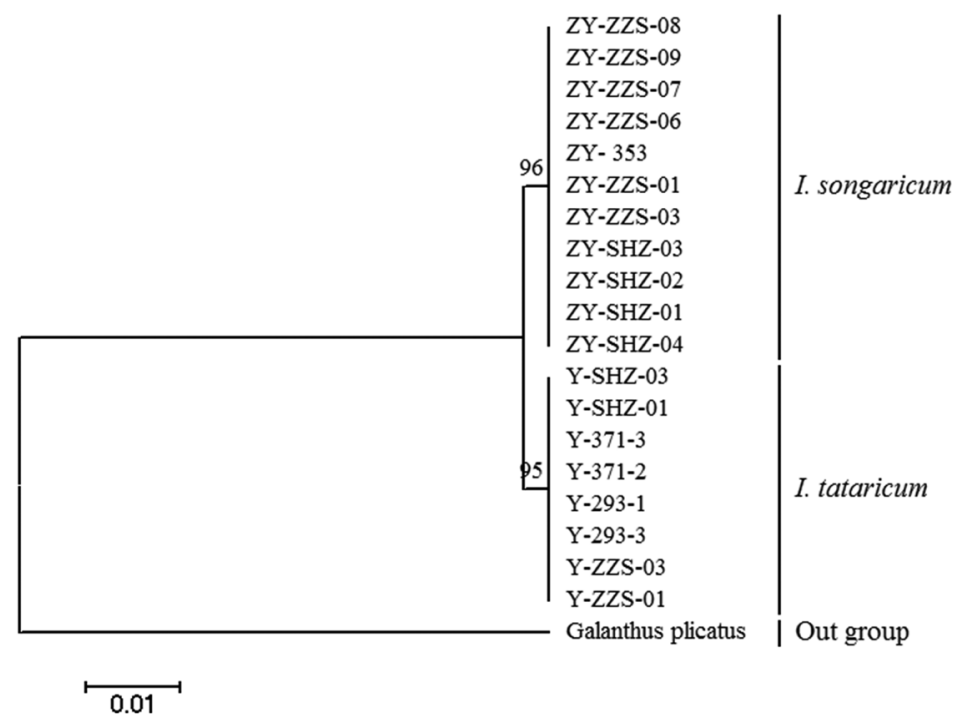

Figure 3. Neighbor-joining tree of Ixiolirion species inferred from matK sequences. Bootstrap values greater than $50 \%$ are shown above branches. Species are shown to the right.

\section{DISCUSSION}

Species-discriminatory power is an important criterion for selecting DNA barcodes (Hebert et al., 2004; Kress and Erickson, 2007; CBOL Plant Working Group, 2009). Indeed, 
an ideal DNA barcode should provide high species discrimination and identification (Kress et al., 2005; Hollingsworth et al., 2009). A 2-marker combination, composed of rbcL and matK, was proposed as a core barcode for land plants (CBOL Plant Working Group, 2009). Similarly, ITS was proposed to be the core barcode for seed plants (China Plant BOL Group et al., 2011). In the present study, 3 DNA barcodes were used to identify Ixiolirion species, including ITS, trnL intron, and matK. rbcL was not utilized in this study because of its relatively low-discriminating power at the species level, as demonstrated in angiosperms (CBOL Plant Working Group, 2009). Species discrimination is considered successful if the minimum uncorrected inter-specific P-distance involving a species is larger than its maximum intraspecific distance (CBOL Plant Working Group, 2009), or if all individuals in a species form a monophyletic group in the phylogenetic tree (Hollingsworth et al., 2009).

Each of the 3 DNA barcodes studied here showed an inter-specific P-distance that was larger than the intra-specific distance for the 2 species. MatK and trnL intron showed relatively low-sequence divergence with an intra-specific distance of 0 and inter-specific P-distances of only 0.5 and $0.6 \%$, respectively. ITS sequences exhibited the highest interspecific distance $(8.3 \%)$ and very low intra-specific distances ranging from $0-0.1 \%$. Previously, ITS was considered problematic and rejected from incorporation into the core plant barcode to prevent potential pitfalls, including incomplete lineage sorting, inter-specific inhomogeneity, divergent paralogous copies within individuals, and pseudogenes (Alvarez and Wendel, 2003; Chase et al., 2007; Starr et al., 2009; Hollingsworth et al., 2011). However, none of these potential drawbacks were observed for ITS in this study. Interestingly, recent analysis of a large data set found that ITS was non-problematic for most samples (China Plant BOL Group et al., 2011).

All samples for each species were assigned to a single-monophyletic group (clade) in the NJ tree inferred from individual barcodes (Figures 1-3), indicating that the 2 species were successfully identified and discriminated.

Based on high level of success in PCR and sequencing, high-sequence variation between species, and high-resolution species, the ITS region is the most appropriate barcode for identifying Ixiolirion species. These data confirmed the existence of 2 Ixiolirion species in China.

\section{CONCLUSIONS}

DNA barcoding is a useful approach for species identification, particularly for closely related species or species with complex morphology. Here, we found that DNA barcoding efficiently discriminated I. songaricum and I. tataricum, generating data congruent with taxonomy based on morphological properties. In addition, DNA barcoding is an effective tool for species discrimination in Ixiolirion, providing a rapid and accurate means for resolving the taxonomic issues in Ixiolirion.

\section{ACKNOWLEDGMENTS}

We thank the valuable comments of two anonymous referees in a previous draft of this paper. Research supported by the National Natural Science Foundation of China (Grant \#41061009). 


\section{REFERENCES}

Alvarez I and Wendel JF (2003). Ribosomal ITS sequences and plant phylogenetic inference. Mol. Phylogenet. Evol. 29: 417-434.

Bremer B, Bremer K, Chase M, Fay M, et al. (2009). An update of the Angiosperm Phylogeny Group classification for the orders and families of flowering plants: APG III. Bot. J. Linn. Soc. 161: 105-121.

Cakilcioglu U, Khatun S, Turkoglu I and Hayta S (2011). Ethnopharmacological survey of medicinal plants in Maden (Elazig-Turkey). J. Ethnopharmacol. 137: 469-486.

CBOL Plant Working Group (2009). A DNA barcode for land plants. Proc. Natl. Acad. Sci. U. S. A. 106: 12794-12797.

Chase MW, De Bruijn AY, Cox AV, Reeves G, et al. (2000). Phylogenetics of Asphodelaceae (Asparagales): an analysis of plastid $r b c L$ and $t r n L-F$ DNA sequences. Ann. Bot. 86: 935-951.

Chase MW, Cowan RS, Hollingsworth PM, van den Berg C, et al. (2007). A proposal for a standardised protocol to barcode all land plants. Taxon 56: 295-299.

China Plant BOL Group, Li DZ, Gao LM, Li HT, et al. (2011). Comparative analysis of a large dataset indicates that internal transcribed spacer (ITS) should be incorporated into the core barcode for seed plants. Proc. Natl. Acad. Sci. U. S. A. 108: 19641-19646.

Doyle JJ and Doyle JL (1987). A rapid DNA isolation procedure for small quantities of fresh leaf material. Phytochem. Bull. 19: 11-15.

Govaerts R (2011). World Checklist of Ixioliriaceae. Facilitated by the Royal Botanic Gardens, Kew. Published on the Internet. Available at [http://apps.kew.org/wcsp/].

Hebert PD, Stoeckle MY, Zemlak TS and Francis CM (2004). Identification of birds through DNA barcodes. PLoS Biol. 2: $\mathrm{e} 312$.

Hollingsworth ML, Andra Clark A, Forrest LL, Richardson J, et al. (2009). Selecting barcoding loci for plants: evaluation of seven candidate loci with species-level sampling in three divergent groups of land plants. Mol. Ecol. Resour. 9: 439-457.

Hollingsworth PM, Graham SW and Little DP (2011). Choosing and using a plant DNA barcode. PLoS One 6: e19254.

Khatun S, Parlak KU, Polat R and Cakilcioglu U (2012). The endemic and rare plants of Maden (Elazig) and their uses in traditional medicine. J. Herb. Med. 2: 68-75.

Kim JH, Kim DK, Forest F, Fay MF, et al. (2010). Molecular phylogenetics of Ruscaceae sensu lato and related families (Asparagales) based on plastid and nuclear DNA sequences. Ann. Bot. 106: 775-790.

Kress WJ and Erickson DL (2007). A two-locus global DNA barcode for land plants: the coding $r b c L$ gene complements the non-coding trnH-psbA spacer region. PLoS One 2: e508.

Kress WJ, Wurdack KJ, Zimmer EA, Weigt LA, et al. (2005). Use of DNA barcodes to identify flowering plants. Proc. Natl. Acad. Sci. U. S. A. 102: 8369-8374.

Li FW, Kuo LY, Rothfels CJ, Ebihara A, et al. (2011). rbcL and $m a t K$ earn two thumbs up as the core DNA barcode for ferns. PLoS One 6: e26597.

Qian XH (1984). Notes on Ixiolirion of China. Bull. Bot. Res. 4: 157-158 (in Chinese).

Regel K (1878). Kolpakowskia ixiolirioides Regel. Acta Hort. Petrop. 5: 635 (Lineam Fl. Mansh.).

Regel K (1879). Ixiolirion kolpakowskianum Regel. Acta Hort. Petrop. 6: 494 (Lineam Fl. Mansh.).

Starr JR, Naczi RF and Chouinard BN (2009). Plant DNA barcodes and species resolution in sedges (Carex, Cyperaceae). Mol. Ecol. Resour. 9 (Suppl 1): 151-163.

Taberlet P, Gielly L, Pautou G and Bouvet J (1991). Universal primers for amplification of three non-coding regions of chloroplast DNA. Plant Mol. Biol. 17: 1105-1109.

Tamura K, Peterson D, Peterson N, Stecher G, et al. (2011). MEGA5: molecular evolutionary genetics analysis using maximum likelihood, evolutionary distance, and maximum parsimony methods. Mol. Biol. Evol. 28: 2731-2739.

Townsend CC and Guest E (1985). Flora of Iraq. In: Ministry of Agriculture and Agrarian Reform, Baghdad, 8: 1-440.

White TJ, Bruns T, Lee S and Taylor J (1990). Amplification and Direct Sequencing of Fungal Ribosomal RNA Genes for Phylogenetics. In: PCR Protocols: A Guide to Methods and Applications (Innis MA, Gelfand DH, Sninsky JJ and White TJ, eds.). Academic Press, New York, 315-322.

Yan P (1995). A study on taxonomy of the genus Ixiolirion in Xinjiang. J. Shihezi Agric. Coll. 2: 1-4 (in Chinese). 